\title{
Same river same rules? - Administrative barriers in the Danube countries
}

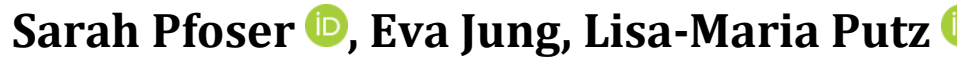

University of Applied Sciences Upper Austria, Franz-Fritsch-Straße 11, 4600 Wels, Austria

\section{open 2 access cc dol}

Article history:

Received: August 09, 2018

1st Revision: September 05, 2018

Accepted: November 29, 2018

\section{DOI:}

10.14254/jsdtl.2018.3-3.2
Abstract: The Danube River Basin is shared by 19 countries, which makes it the world's most international river basin. More than 81 million people of different cultures and languages live in the Danube Basin and they all are interconnected through the widely ramified water system of the Danube. The cultural variety is not only a valuable attribute of this region, but it also causes barriers related to the transport of goods and passengers on the Danube waterway and its navigable tributaries. The abundant existence of administrative barriers in Europe limits the economic and environmental potentials of inland waterway transport (IWT) as a sustainable mode of transport. These administrative barriers consist for example in reporting requirements that vary considerably among fairway authorities and Danube countries. Most often, reports or data provided cannot be re-used across countries or is not available requiring additional input or additional reporting activities by the barge operator. The objective of this paper is to identify administrative barriers for IWT on the Danube and develop solutions for improved procedures and processes. Data is collected from a dense network of stakeholders operating along the Danube. National focus groups were held to analyse the procedures and administrative processes in inland waterway transport and identify barriers. Further, an online-survey has been set up to collect data. Potential solutions are developed in a cooperative way together with involved operators and authorities.The philosophy of lean administration suggests that non-value added activities ("waste") must be identified in a first step to make processes more efficient. A diverse number of nonvalue added administrative barriers were therefore identified in the countries along the Danube. Afterwards, Port Community Systems are introduced as a possible solution to overcome administrative barriers.

Keywords: inland waterway transport, administrative processes, lean management, Danube River. 


\section{Introduction}

The Danube River can be described as a backbone of Europe, positioned horizontally and connecting Eastern and Western Europe as it rises in the Black Forest in Germany and empties into the Black Sea in Romania and the Ukraine. The Danube River Basin is shared by 19 countries, which makes it the world's most international river basin. More than 81 million people of different cultures live in the Danube Basin and they all are interconnected through the widely ramified water system of the Danube. The cultural variety in this region encompasses many different languages with various origins (Slavic, Latin and Anglo-Saxon), but also different religions (Orthodox, Protestant and Catholic) (Lates \& Costache, 2014). The Danube region even appears with their own supranational governing structures, i.e. the Danube Commission.

There have also been conflicts between the different users of the Danube River throughout the history. This was especially the case at the time of the collapse of the Soviet authority and the rise of nationalism in the region, e.g. in the former Yugoslavia (Linnerooth-Bayer, \& Murcott, 1996). In the meantime, a cooperative Danubian organisational structure has been created and there is a strong motivation to facilitate a strong economic and sustainable development in this region.

The focus of this paper is on the Danube River as an enabler for sustainable waterway transport. Inland waterways such as the Danube demonstrate several advantages in comparison to other ways of transport (e.g. roads or railways). For example, inland waterways feature the lowest specific energy consumption and the lowest external costs of any land transport mode. Furthermore, large quantities of goods per unit can be transported and comparably low investment costs to maintain inland waterways is required (Viadonau, 2013).

The advantages mentioned above suggest that it is beneficial to use the Danube River for transport purposes. Over the last few decades, ports on the Danube have undergone a substantial transformation from conventional inland ports to modern logistical hubs. Despite that there is a fundamental obstacle which can be attributed to the fact that there are so many riparian countries and a high cultural diversity in the Danube region. Administrative barriers in the logistics of freight and passengers on the Danube waterway and its navigable tributaries are a major obstacle for the efficient and sustainable use of the Danube as main transport axis of the region (Visser, 2008; Mircetic et al., 2017). The abundant existence of administrative barriers reduces the economic and environmental potentials diminishing economic growth and social welfare in the entire region. For this reason, the purpose of this paper is to identify administrative barriers in the Danube countries and propose potential solutions for their elimination.

\section{Literature review}

Strategies and policies around the world stress the importance of creating sustainability to ensure a positive long-term vision of society, which is worth living for current and future generations. Economic growth and social progress must be connected with sustainable development towards a cleaner, safer and healthier environment. Currently, climate change has already caused problems such as floods, droughts, heat waves or other severe consequences that damage the wellbeing of planet earth and our society. One main driver of climate change and global warming are greenhouse gas emissions, such as carbon dioxide (European Commission, 2001; Steffen et al., 2015).

Freight transport represents the most environmentally harmful area in the field of logistics. The total transport-sector accounted for $23 \%$ of global CO2 emissions and for $15 \%$ of overall greenhouse gas emissions in 2010. Forecasts indicate that freight volume will quadruple by 2050 (OECD/ITF 2013) which consequently may lead to an increase in ecological, economic and social problems. Rises in energy costs, the bottlenecks in transport infrastructure, as well as public and political pressure, indicate a need for sustainable transport solutions (Bretzke \& Barkawi, 2013). In Europe road transport had the highest share of the modal split, with $74.9 \%$ in 2014 in the European Union. The sustainable transport modes railway accounted for $18.4 \%$ and inland waterway for $6.7 \%$ of the European modal split (European Commission, 2016).

In order to achieve the European greenhouse gas emissions, goal a cut of $60 \%$ in $\mathrm{CO} 2$ emissions for the transport sector compared to 1990 level is claimed by the European Union. A shift to more sustainable transport modes such as inland waterway or railway is required to decrease emissions and ensure a sustainable future (European Commission, 2011). 
Compared with rail and road, inland waterway represents the most sustainable transport mode in Europe (European Commission, 2011). The main advantages of freight transport on inland waterways are the high energy-efficiency, low emissions compared to rail and road, the lowest noise level and low infrastructural costs. Waterborne transport allows for high-capacity and heavy load transport. Moreover, due to the high loading capacities the transport costs per tonne are really low (DirectorateGeneral for Internal Policies, 2010; Mihic et al., 2011). A major geographical area in the European strategy is represented by the Rhine Maine Danube corridor. The Danube River is an integral part of the Trans European Transport Network (TEN-T network) and represent one of the most important rivers in economic and strategic values in Europe (Mihic et al., 2011).

However, the share of inland waterway transport has decreased in the last years, while road transport increased. One measure to enhance competitiveness of the waterborne transport is to decrease administrative barriers. Cross-border transports require countless completed paper-based documents that require resources (i.e. time leading to monetary necessities) from all involved stakeholders. Digitalization and cooperation between the involved parties would support the European goal to increase the competitiveness of the inland waterway sector (Bierau-Delpont et al., 2019; Mihic et al., 2011).

\section{Methodology}

We collected data about administrative barriers from two sources, using a dense network of relevant stakeholders operating in the public and private sector along the Danube. First, a long-term online survey was set up allowing stakeholders to list administrative barriers they experienced during their everyday business. The survey was available in eight different languages ("Danube languages" and English) which intended to encourage actors to participate in the survey. Users of the Danube waterway for passenger transport and freight transport have been selected as relevant target group of the survey because they are the ones that experience administrative barriers. The setup of the survey allowed reporting incidents of administrative barriers that occurred along the Danube. The survey questions asked respondents to provide the following specific information about their incidents:

- The country in which the incident was faced (drill down menu of the countries)

- The river on which the incident was faced (drill down menu: Danube (default), Danube-Black Sea Canal, Drava, Sava, Tisza, Serbian waterway network, other - if other is selected, a new box is displayed to type in the name of the river)

- Location of the incident (city and / or river kilometre)

- The date when the incident was faced (DD/MM/JJ; Time XX:YY)

- Type of authorities involved in the incident (Border police, Tax \& Customs, Navigation / traffic control authorities, Port authorities / administrations, Waterway and Canal administrations, Other relevant authorities, Unknown authorities)

- Description of the incident in a text box

- Optional there is the possibility to upload any documents related to the incident

- Function of reporting person and organisation, country

The structure of the survey was therefore divided into three main parts: (1) Key data about the incident (2) Detailed description of the incident (3) demographic data of the respondent. On the whole, 108 incidents were reported in the period from May 2015 until October 2017. The data describing these incidents was collected in an Excel file and thoroughly structured and categorised. Content analysis has been used to analyse quantitative and qualitative aspects within the collected data and to assess structural (descriptive) as well as content criteria (Brewerton \& Millward, 2001).

The second data source were national focus groups which are organised to analyse the procedures and administrative processes in inland waterway transport and identify barriers face-to-face with the stakeholders in the Danube countries. In this way, potential solutions can be developed in a cooperative way together with involved operators and authorities. Between May and July 2017 seven focus groups were organised in six different Danube countries with 182 participants.

Data was collected from different organisations, such as ports, cruise operators, associations and border police. Danube. The barriers were categorized in different types of IWT operations, i.e. border 
police/tax/customs, navigation/traffic control authorities, port authorities/administrations, waterway/canal administrations and other relevant authorities such as health control or disaster management. All data collected was summarised in a database that serves as a basis for further analysis. Moreover, this database is intended to develop recommendations for the reduction of administrative barriers. The data was collected completely anonymously in order to ensure the privacy of the participants and to avoid social desirability bias (Trochim et al., 2016).

\section{Results: Administrative barriers along the Danube}

The widespread concept of lean management is a systematic approach to identify and eliminate waste, defined as non-value-added activities, through continuous improvement. The roots of lean management lie in the manufacturing and production sector. The term "lean production" was first used by in 1990 by Womack et al. in their famous book "The Machine that Changed the World" (Womack et al. 1990).

In the recent past, lean practices have also been adapted into the administrative area. It is estimated that $60 \%$ to $80 \%$ of all costs associated with meeting a customer's demand are related to administrative processes (Tapping, \& Shuker, 2003). This illustrates why it is fundamental to recognize the importance of these administrative areas and optimise these processes too. The main difference between Lean Production and lean administration is that in lean production the processes and the outputs of these processes are highly visible since they consist in physical flows and products. Instead, administrative processes and outputs are predominantly intangible, such as information flows. This is why administrative tasks and functions are often not well defined (Locher, 2011).

The essential first step of introducing lean administration is to identify waste in order to be able to optimise processes by removing waste (Tapping 2005). We used the data collected from the online survey and the focus groups to identify which non-value added activities (waste) occur in Danube inland waterway transport. In the following, we will give an overview of the most critical issues that occur in the Danube countries.

\subsection{Border controls}

Most of the problems that were mentioned in the data collection process refer to border controls. The data reveals that more or less the same checks, for example border control procedures or notice of arrival and departure at ports, have to be done in every county and port. For these procedures a great number of authorities are involved. Documents including the same information are required in every country. The following responses underline this problem:

„For border control 10 documents (six for immigration police and four for customs) necessary. Available in Hungarian, German, English and Russian -> For in and out 20 documents necessary"

„[...] These 7 documents must be uploaded to an internet platform called BULRIS and all institutions which are involved [...]. In case the ship takes entry revision in one port and exit to another the ships must prepare these 7 documents FOR EACH PORT [...] it is not only the scanning of the passports but also the uploading and checking of all these new documents"

„[...] authorities all want to see original documents and are not willing to check the plates. The biggest problem appears when a barge/ship changes owner and original docs must be given to its homeport authority, thus no original can be provided on board. Several such cases occurred and led to big delays until matter could be solved/explained to Water Police"

The average time consumption that was reported by the countries is 2 hours for border controls. In Hungary, time consumption for border controls can be even up to 4 hours. Croatia (Port of Vukovar) was mentioned as a good practice example in this context, as border controls only take about half an hour there. 


\subsection{Staff shortage}

The lack of motivated and well-prepared staff for port activities is a problem. This is already a global problem for the river industry. The lack of qualification training centres deepens the problem of staff shortages, as it is known that in this education system, high-quality staff cannot be expected to come from secondary schools. Staff shortage may result in tremendous waiting times. In Romania for example there is no customs present at Port of Harsova (only border police employees), so there is no in-out revision possible. Also, a lack of personnel for phytosanitary controls at all Romanian inland ports has been reported, which results in long waiting time. For revision / customs in Romania is only one employee available for 140 passengers and in Bulgaria there is only one employee in charge for checking the passports of 160 passengers and 50 crewmembers. In Mohács / Hungary it has been stated that there is a waiting time of up to six hours for border control in case several ships arrive at the same time. Additionally, there is a lack of qualification training centres in Bulgaria, which deepens the problem of staff shortage.

\subsection{Charges \& fees}

Non-transparency and inconsistency of charges and fees among Danube Countries are also a problem in Danube navigation. In the following, we list some comments related to the issue charges and fees:

"Giurgiu: It changes the tariff from one day to the next and they are even increa-sed 3 times. [...] There are huge taxes and zero service"

\section{„The fees are calculated with a complex calculation"}

„For transit through the Danube - Black Sea Channel, its administration apply char-ges taking into consideration the total capacity of the convoy and not the quantity of cargo transported. Since July 1, 2014, the National Company - Administration of the Navigable Canals SA (CN ACN SA) has unreasonably increased transit fees. For empty convoys, these fees were increased with $80 \% "$

„Today we will pass [...] with 6 empty units. But the Channel Administration will charge us as top-ofthe-line units, as charging is done on tonnage, not depending on the quantity of cargo transported. [...]

There exist transit charges for the Black Sea-Danube Canal which are calculated based on ship's capacity and not on actual quantity of loaded cargo. This is perceived to be unfair because there are situations when the level of the Danube draught does not allow the loading of vessels until the maximum capacity (e.g. 1,000 tons of cargo loaded into a ship of 3,000 tons capacity). Therefore, this issue is especially critical in periods of low water.

Also in Romania, a tax for surveillance of the safe navigation has to be paid, which does not occur in any other country. Critically mentioned was that there is no transparency offered by the ports/canals administration for these fees (required by RO laws). These fees apply to each port entrance. So if a ship enters in the same day in three different ports, it will pay each time the surveillance and the traffic control fee as well as the entry / exit formalities. Complaints about the surveillance fee have also been entered into the electronic reporting tool several times for several Romanian ports.

In Slovakia, empty vessels waiting for cargo and vessels under repair are subject to port charges. In Ukraine, however, no fee has to be paid during the repairing (the vessel is discontinued from the business). It is perceived unfair that in Slovakia it has to be paid for the ships even though they do not make any profit.

In Serbia, the fees are calculated in a complex way, which makes it non-transparent and subject to complaints.

Not only fees but also fines are divergent along the Danube countries. A problem discussed in Bulgaria are fines for the non-compliance with low-water draft limitations. At km. 567, the "closure of navigation" occurs most frequently, with neither passenger ships, nor any other ship being able to pass, because a discourteous captain has not complied with the prescriptions of the competent authorities. 
The reason is that the legal fines are too low in Bulgaria (maximum BGN 1000) and some companies pay the fines and order their captains to violate the ban. In contrast, in Hungary, the thresholds are made of stone and the ships that exceed the draft limitations must wait for that reason, but more importantly, the punishment is not only a fine, but it is also provided that the captain's license can be revoked for three months.

Another issue is that the Ruse-Passau line is not treated as a Ro-Ro line but as a conventional ship in terms of charges and fees.

Overall, a harmonisation and a creation of transparency of charging policies has to be induced among European inland waterways in order to create predictability and security for inland navigation operators.

\subsection{Working hours of ports \& customs}

Differing working hours or inconvenient schedules are also a problem that causes waiting time, which is mentioned in several responses to the survey:

\section{„Problem is limited working hours at certain locations"}

\section{„Different working hours (some 24/7 opened; some only from 7:30 - 15:30 on working days or only per request)“}

„Buy fuel without excise, but bunker is a problem, at Giurgiu port is the biggest problem, often the tank arrives in the evening or Friday and stay until the next day, or until Monday. Their work program is 8 hours, although the website states that the work program runs between 08:00 and 23:00. You cannot stay for 2-3 days at customs for gasoline supply. On different shifts, the same document was good and bad. Request operational teams and 24/7 customs assistance"

For example, some ports in Serbia have operating hours of just eight hours per day, the customs office in Romania is closed after $4 \mathrm{pm}$ on work days and the whole day at weekends, which leads to waiting times of up to 36 hours. In Bulgaria documents of passenger ships and cargo ships cannot be processed during the night, what also causes delays up to six hours. A possible solution for the problem of inconvenient work schedules causing long waiting times would be to establish round-the-clock checkpoints.

\subsection{Languages}

The wide variety of languages that is used at the radio and in other communication channels is also a crucial issue. In marine navigation, English is a generally accepted language, but for Danube inland navigation there is no general consent as the dominant language differs from region to region. While German is clearly the dominant language on the western part of the Danube-Rhine-Maine line, at the eastern part rather Russian is the commonly known language.

As per the language used along the Danube, the employees of the Water police in Hungary indicated that opportunity was given to their employees to learn languages and its importance is also taken into consideration in the form of a university education. However, it is difficult for the employees to choose the language to learn since it cannot be reasonably expected from navigation professionals to speak 3 languages. Considering that English is a widely spoken language, it might be a generally accepted language on the Danube in the future; however, this might be difficult at the Rhine and Maine, where German is the dominant language.

The report from activity 4.1 gives a quite detailed overview how many documents are available in which languages in the different Danube countries. The border control documents are typically available in a variety of languages, namely in the national language and most often in other languages such as English or German or Russian. On the one hand, this is good, but on the other hand the more documents in different languages, the higher the possibility of having mismatching documents. Also, there exist a lot of other documents which are not available in different languages. 
From an international perspective, navigation on the Danube would be more effective if the principle of "same river - same rules" would be applicable on all territory. This applies also for the process of choosing the language used in practice, which would facilitate the communication of the ships residing in foreign countries with the authorities on the long term.

\subsection{Insufficient infrastructure \& equipment}

Another barrier providing an obstacle for efficient processes is insufficient infrastructure and equipment. Two examples for responses on this issue are:

„It is necessary to introduce and improve electronic forms of communication. Each vessel is not equipped with an Internet connection. Therefore, it is necessary to establish communication points in ports with free Wi-Fi connection to enable the captains of vessels to connect and to communicate more easily on an electronic basis. It will make the administrative process in ports easier, as captains will not have to print the forms needed"

„It would be desirable to have an internet connection in the port, it saves time. It is just an electronic form to send arrival and departure reports directly from the vessel"

Lacking repairs and investments for port infrastructure, missing required software applications and missing drinking water sources in Romanian ports are stated as well as slow working software with interruptions for scanning passports, weak data connection and a lack of copying equipment in Bulgaria. It is necessary to introduce and improve electronic forms of communication. At the moment, not every vessel is equipped with an Internet connection. Therefore, it is necessary to establish communication points in ports with free $\mathrm{Wi}-\mathrm{Fi}$ connection to enable the captains of vessels to connect and to communicate more easily on an electronic basis. It will make the administrative process in ports easier, as captains will not have to print the forms needed and digitalization can be enhanced.

\subsection{Insufficient fairway conditions}

It has been criticised in general that ports administration do not provide any repairs or investments for port infrastructure in Romania and Bulgaria, and specifically there are complaints that fairway depth is insufficient which causes insufficient fairway. Long periods of blockades of river navigation in summer (60-120 days a year) exist because authorities fail to do dredging and maintenance works. For example, we received the following response to our survey:

"Because of the insufficient depth in the fairway, in the transition from $\mathrm{km} 568$ (up-stream Zimnicea), we had to anchor the convoy and pass into groups of 1 unit. This implies additional consumption and considerable delays. The sector is managed by Bulgaria, which for many years has not performed dredging maintenance works or other works."

\subsection{Qualification, education \& skills}

Due to the missing standards along Danube River in terms of qualification, education and skills there are problems of missing port operator qualifications in Hungary or inappropriate communication behaviour in Romania. There is a lack of motivated and well-prepared staff. Due to a lack of qualification training centres and practical lessons, employees often have to learn on their own how to do all the paperwork and cope with the daily business. Some responses regarding qualification of employees:

„[...] The staff at Giurgiu Customs are very often not present for duty during the program or it is drunkenness. Generally incompetent staff with no civilized communication skills"

„[...] There are people who do not know and do not understand what the activity means because they are not qualified in this field of activity." 
„[...] The border authorities wanted to speak to the passenger personally who was a pregnant lady. Me as the captain of the ship went together with the lady to the building of the border control. I asked the personnel's from the authorities to allow the lady to sit down. However the officer on dute was shouting to me and the lady without any particular reason in this situation [...] The problem was solved till next morning and we continued our trip to Budapest with a several-hour delay."

The acceptance of specific qualifications from other countries is also a problem. It has been criticised that a Red Cross certificate from Romania was not accepted by the German water police or that a Bulgarian "Certificate for Sailing with a Radar" or other qualifications of Bulgarian seafarers are not recognized in the Rhine region:

„The crew problem: in Germany, if a seaman has the necessary training, he can become a wheelchair for a fee of 10 Euro, in Romania, the same sailor to reach the wheelhouse costs 7,000 Lei additional courses and has a validity of 5 years. This should be valid for life. If he graduated in Germany, he is not recognized in Romania, he has to follow the one organized by the Romanian authorities"

„[...] in Germany the first aid courses are followed at the Red Cross and are recognized, and in Romania this is not the case."

\subsection{Information gaps}

Lack of information also causes inefficiency in some cases. For example, the lack of an electronic map on the Hungarian part of the Danube has been reported (but a bathymetry map shall be available soon). In case of any unexpected issues at Gabčíkovo locks in Slovakia, information is provided too late, which makes it difficult to react in an appropriate way. Better information was requested by several respondents, as expressed in the following quotes:

„In case of any unexpected issues - we're getting information too late“

„More punctual data information from the fords [is needed], and update them more often“

\section{Potential solutions and recommendations}

The philosophy of lean administration suggests that non-value added activities (=waste) must be eliminated to remove or at least reduce the impact of the administrative barriers in the Danube countries. Regarding the reported facts and problems, it became clear that in all countries that provided input there are more or less the same traffic control procedures in order. There are several authorities responsible for similar controls in ten countries. Furthermore, the required documents are not standardized and available in very different languages. Harmonization of these procedures and documents would make it easier. If the checks were more standardized time consumption could be reduced as well. In the recent years, a new technology has emerged which aims to facilitate a more efficient movement of goods in ports while allowing customs and other government departments to maintain effective controls of these processes (Long 2009). This technology is called Port Community System (PCS) and may serve as valuable instrument to manage administrative barriers in inland waterway transport.

A Port Community System optimises port processes by digitalizing them (instant delivery of necessary information), reusing the data already available within the system (to avoid unnecessary repetitive filling of forms, which was one of the main barriers mentioned in the online survey and the focus groups) and smart and secure data exchange (where only the appropriate port actors have access to each of the available data fields) (van Baalen et al., 2009).

PCS are established to enable the information distribution among the parties in the network to facilitate freight movement throughout the process. Involved parties include terminal operators, carriers (waterways, road and/or rail), freight forwarders, enforcement agencies (i.e. customs), port 
authorities, and various lobby groups (including workers' unions, environmentalists, and other policy makers) (Srour et al., 2008). Improved information sharing can abolish many of the above mentioned barriers, e.g. staff can be allocated better in advance in case that there is sufficient information about expected arrival times of ships and waiting times can be reduced this way.

In the long term, Blockchain technologies have the potential to contribute to the efficient digitization of administrative processes as they facilitate trusted data sharing between all relevant stakeholders (Weernink et al., 2017). Blockchain has the potential to further upgrade existing PCS technologies. For example, Blockchain can be used as a means to store information. Instead of exchanging documentation via PCS, the parties involved in the process are granted permission to access the block where the information is stored. This leads to the creation of a unique, shared piece of information which can be accessed in real-time and with lower transaction costs.

Beside the positive effect of digitization, a Port Community System supports another solution approach which originates from the lean philosophy: Standardisation. Standardisation means the development of practices which are consistently followed by all people who perform a process or activities linked to the process (Locher, 2011). As a result, there will be less variability in the processes and thus they will be simplified and less time consuming. In the context of Danube inland waterway transport, standardised procedures and practices could lead to less paperwork which is highly desirable given the barriers that have been described above.

The above mentioned measures have been specifically developed for the Danube region which is the geographic focus of this paper. However, there are some underlying general recommendations which can be also transferred to other river basins in the world. Establishing and implementing a seamless cross border transport is important for every inland waterway transport service in the world to create more efficiency. Improving the interoperability of digital interfaces in inland waterway transport is an effective measure in that regard. Establishing a one-stop-shop enables waterway users to receive all information and services from one single contact point, which again facilitates better processes. Finally, digitalisation allows for more efficient information sharing by eliminating paperwork.

\section{Conclusion}

Transnational cooperation is decisive in making macro-regional strategies work. One such strategy in the Danube region is to achieve a modal shift from road to the environmentally friendly Danube waterway. However, administrative barriers across the Danube countries represent a severe barrier for this strategy. A crew navigating the Danube River from Bavaria to the Black Sea needs to overcome substantial administrative barriers across the countries e.g. to fill in a very high number of forms in different languages.

The provision of better framework conditions for the use of inland waterway transport is in line with the strategy of the European Union towards a competitive and resource efficient transport system. A clear set of strategic policy goals exists that aim to increase the modal share of waterways and the cargo volumes transported on the Danube River. Removing the administrative barriers of inland waterway transport will contribute to achieve these goals and provide manifold benefits, such as greater transparency of the processes, better definition of priorities in the tasks to be performed and better organization and work time management in the Danube ports concerned. The fight of administrative barriers and the derived higher logistics cost is also one the priorities of the European Commission's current transport policy agenda. The paper revealed some of the inefficiencies that predominate administrative processes in the Danube inland waterway business and elaborated on Port Community Systems as a potential solution to overcome these barriers.

Limitations of this study are related to the geographic focus which is restricted to the Danube area. Further research is needed to analyse if the same administrative barriers also occur in other river basins of the world. We also suggest further research to capture data from public authorities, e.g. expert interviews with representatives from port authorities on administrative issues. The current study mainly includes data from private companies that are active in Danube inland waterway shipping. Bringing all the stakeholders together to discuss about problems and possible solutions would be an important step to improve the situation and promote a modal shift towards inland waterways. 


\section{Acknowledgements}

The results are part of the project DANTE (Interreg Danube Transnational Programme DTP1-455-3.1).

\section{Citation information}

Pfoser, S., Jung, E., \& Putz, L.-M. (2018). Same river same rules? - Administrative barriers in the Danube countries. Journal of Sustainable Development of Transport and Logistics, 3(3), 27-37. doi:10.14254/jsdtl.2018.3-3.2.

\section{References}

Bierau-Delpont, F., Müller, B., Napoletano, L., Chalkia, E., \& Meyer, G. (2019). Building an action plan for the holistic transformation of the European transport system. In Towards User-Centric Transport in Europe (pp. 3-14). Springer, Cham.

Bretzke, W. R., \& Barkawi, K. (2012). (2013): Basics. In Wolf-Rüdiger Bretzke, Karim Barkawi (Eds.): Sustainable logistics. Responses to a global challenge. Berlin, Heidelberg: SPRINGER (Lecture Notes in Logistics), (pp. 1-84).

Brewerton, P. M., \& Millward, L. J. (2001). Organizational research methods: A guide for students and researchers. Sage.

Directorate-General for Internal Policies. (2010). The future of sustainable freight transport and logistics. Brussels, Belgium: European Parliament.

European Commission. (2001). Communication from the Commission A Sustainable Europe for a Better World: A European Union Strategy for Sustainable Development. COM/2001/0264 final. Brussels.

European Commission. (2011). Roadmap to a Single European Transport Area - Towards a competitive and resource efficient transport system. COM(2011) 144 final. Brussels.

European Commission. (2016). Energy, Transport and Environment Indicators. Luxembourg: Publications Office of the European Union (Eurostat Statistical Books).

Lates, G., \& Costache, M. (2014). The Intercultural Danube-a European Model. Journal of Danubian Studies and Research, 4(2), 16-21.

Linnerooth-Bayer, J., \& Murcott, S. (1996). The Danube River Basin: international cooperation or sustainable development. Natural resources journal, 36(3), 521-547.

Locher, D. (2011). Lean Office and Service Simplified. The Definitive How-to Guide. New York: Productivity Press.

Long, A. (2009). Port community systems. World customs journal, 3(1), 63-67.

Mircetic, D., Nikolicic, S., Bojic, S., \& Maslaric, M. (2017). Identifying the Barriers for Development of Inland Waterway Transport: a Case Study. In MATEC Web of Conferences (Vol. 134, p. 00039). EDP Sciences.

Mihic, S., Golusin, M., \& Mihajlovic, M. (2011). Policy and promotion of sustainable inland waterway transport in Europe-Danube River. Renewable and sustainable energy reviews, 15(4), 1801-1809. doi:10.1016/j.rser.2010.11.033.

OECD/ITF. (2013). Transport for Growth. ITF Transport Outlook 2013. Paris: International Transport Forum; Organization for Economic. Retrieved from http://dx.doi.org/10.1787/9789282103937-6-en.

Srour, F. J., van Oosterhout, M., van Baalen, P., \& Zuidwijk, R. (2008). Port community system implementation: Lessons learned from international scan. In Transportation Research Board 87th Annual Meeting, Washington $D C$.

Steffen, W., Richardson, K., Rockström, J., Cornell, S. E., Fetzer, I., Bennett, E. M., ... \& Folke, C. (2015). Planetary boundaries: Guiding human development on a changing planet. Science, 347(6223), 1259855. doi:10.1126/science.1259855.

Tapping, D. (2005). The Lean Office Pocket Guide: Tools for the Elimination of Waste in Administrative Areas!. MCS Media, Inc..

Tapping, D., \& Shuker, T. (2003). Value Stream Management for the Lean Office: Eight Steps to Planning, Mapping, \& Sustaining Lean Improvements in Administrative Areas. Productivity Press.

Trochim, W., Donnelly, J. P., \& Arora, K. (2015). Research methods: The essential knowledge base. Boston, MA: Cengage.

Van Baalen, P., Zuidwijk, R., \& Van Nunen, J. (2009). Port inter-organizational information systems: Capabilities to service global supply chains. Foundations and Trends® in Technology, Information and Operations Management, 2(2-3), 81-241. 
Viadonau. (2013). Manual on Danube Navigation. Edited by Thomas Hartl, Vera Hofbauer. Vienna, Austria: viadonau - Österreichische Wasserstraßen-Gesellschaft mbH.

Visser, Jan A. (2008). Final Report for the "Study on Administrative and Regulatory Barriers in the field of Inland Waterway Transport” - Part A. Zoetermeer, September 2008.

Weernink, M. O., van den Engh, W., Francisconi, M., \& Frida Thorborg (2017). The Blockchain Potential for Port Logistics. TU Delft; Erasmus; Smart Port.

Womack, J. P., Womack, J. P., Jones, D. T., \& Roos, D. (1990). Machine that changed the world. Simon and Schuster.

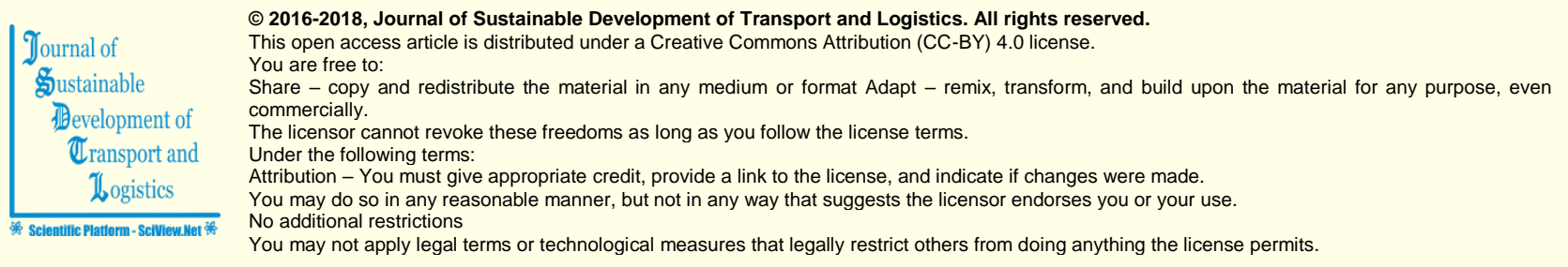

Journal of Sustainable Development of Transport and Logistics (ISSN: 2520-2979) is published by Scientific Publishing House "CSR", Poland, EU and Scientific Publishing House "SciView", Poland, EU

Publishing with JSDTL ensures:

- Immediate, universal access to your article on publication

- High visibility and discoverability via the JSDTL website

- Rapid publication

- Guaranteed legacy preservation of your article

- Discounts and waivers for authors in developing regions

Submit your manuscript to a JSDTL at https://jsdtl.sciview.net/ or submit.jsdt|@sciview.net 